\title{
Occurrence and distribution of organochlorine pesticides (HCH and DDT) in sediments collected from East China Sea
}

\author{
Rui-qiang Yang, Gui-bin Jiang*, Qun-fang Zhou, Chun-gang Yuan, Jian-bo Shi \\ State Key Laboratory of Environmental Chemistry and Ecotoxicology, Research Center for Eco-Environmental Sciences, \\ Chinese Academy of Sciences, Beijing, 100085, China
}

Available online 15 July 2005

\begin{abstract}
Sediments used in this study were collected from different depths of eight sites in East China Sea in November 2002. The levels and distribution patterns of the selected organochlorine pesticides (OCPs $=p, p^{\prime}$-DDT, $o, p^{\prime}$-DDT, $p, p^{\prime}$-DDE, $p, p^{\prime}-\mathrm{DDD}, \alpha-, \beta-, \gamma-$ and $\delta$-HCH) in samples were investigated by the technique of sonication extraction followed by the analysis of gas chromatography (GC) coupled with a micro-electron capture detector $(\mu \mathrm{ECD})$. The concentrations of $\Sigma \mathrm{HCH}$ and $\Sigma$ DDT in the surface sediments were in the range of $<0.05-1.45$ $\mathrm{ng} / \mathrm{g}$ (mean $0.76 \mathrm{ng} / \mathrm{g}$ ), $<0.06-6.04 \mathrm{ng} / \mathrm{g}$ (mean $3.05 \mathrm{ng} / \mathrm{g}$ ) based on dry weight (dw), respectively. In the vertical distributions, the $\Sigma \mathrm{HCH}$ and $\Sigma$ DDT were in the range of $<0.05-2.52 \mathrm{ng} / \mathrm{g},<0.06-10.94 \mathrm{ng} / \mathrm{g} \mathrm{dw}$, respectively. Residues of OCPs varied significantly with different sampling sites. $\Sigma$ DDT in the surface sediments was correlated well with total organic carbon (TOC) content $\left(r^{2}=0.71\right)$, while $\Sigma$ HCH showed no obvious correlation. The distribution showed that the sediments from the vicinity estuary or near shore had higher TOC contents, and higher OCPs concentrations. The contamination record indicated an extensive use of OCPs in the catchments from Yangtze River in the past might greatly affect the OCP residues.

(C) 2005 Elsevier Ltd. All rights reserved.
\end{abstract}

Keywords: OCPs; HCH; DDT; Residue levels; Sediments; East China Sea

\section{Introduction}

Organochlorine pesticides (OCPs), including typical representatives of this group of chemicals such as technical hexachlorocyclohexane $(\mathrm{HCH})$ and 1,1,1-trichloro-2,2-bis(4-chlorophenyl)ethane (DDT), have been extensively studied in the last 30 years, due to their large production and usage, their impact on non-target organisms, bioaccumulation, and persistence in the environment (Woodwell et al., 1971; Tanabe et al., 1982; Iwata et al., 1994; Lee et al., 2001). In aquatic environment, these compounds can enter marine and freshwater ecosystems through effluents release, atmospheric deposition, runoff, and other means (Zhou et al., 2001). Because of the low water solubility, OCPs have a strong affinity for particulate matters. As a result, sediments can serve as

\footnotetext{
* Corresponding author. Tel.: +86 10 62849334; fax: +86 1062849339

E-mail address: gbjiang@mail.rcees.ac.cn (G. Jiang).
}

reservoirs or "sinks" for OCPs (Iwata et al., 1995). When disturbed, however, the sediments can be resuspended, resulting in second contamination. In terms of aquatic environmental monitoring, the residues of OCPs in surface sediments reflect a recent contamination, whereas residues of OCPs in sediments cores may provide historic information over decades (Hong et al., 2003; Hendy et al., 1996).

China is the second world largest pesticides producer. The total production reached 260,000 tons in 1994 . Technical HCH and DDT were the most widely used pesticides in China during 1950s to 1983, and they are officially banned now. The total production of technical $\mathrm{HCH}$ and DDT were about 4.9 and 0.4 million tons, respectively, which accounted for $33 \%$ and $20 \%$ of the total world production (Zhang et al., 2002). Although the residue levels of OCPs in the environment have considerably declined in the past 20 years, they could still be detected in various environment matrixes (Wu et al., 1999; Klumpp et al., 2002). Moreover, some OCPs such as DDT, HCH and 
lindane are still used in some countries around the tropical and subtropical belts for agricultural and medicinal purposes (de Brito et al., 2002). These organic pollutants can be globally redistributed through the atmosphere transportation, and they were detected even in remote Arctic areas (Allen-Gil et al., 1997).

The present work is a small-scale survey of the contamination status and spatial distribution of $\mathrm{HCHs}$ and DDTs in sediments from a special marginal area in the East China Sea, where the inpouring of two large rivers (Yangtze River and Qiantang River) into the East China Sea formed two large estuaries, Yangtze Estuary and Hangzhou Bay. The Yangtze River is the largest river in China. According to the survey of the National Bureau of Coastal Zone Protection during 1980-1987, the organochlorines flux just carried by Yangtze River was 239.3 tons per year, which accounted for $19.8 \%$ of the total flux by Chinese river catchments into the marine coastal sites. Along the coast of the East China Sea, there are some big cities including Shanghai and Ningbo. In addition, a large fishery, Zhoushan Archipelago, is near Hangzhou Bay. The monitoring data in these selected sediments is indispensable for the risk assessment of OCPs in these sites.

\section{Experimental}

\subsection{Materials}

The stock standard solution of composite OCPs including $\alpha$-, $\beta-, \gamma-, \delta$-HCH and $p, p^{\prime}$-DDT, o, $p^{\prime}$-DDT, $p, p^{\prime}$-DDE, $p, p^{\prime}$-DDD was purchased from National Research Center for Certified Reference Materials of China. In the meantime, the corresponding individual standards of OCPs were also prepared for qualitative purpose. The original storage solution was $100 \mathrm{mg} /$ $\mathrm{L}$ in $n$-hexane and further diluted to obtain the desired concentrations. Florisil (100-200 mesh, Beijing Yizhong Chemical Reagent Factory, China) was activated in the oven at 180 ${ }^{\circ} \mathrm{C}$ for $12 \mathrm{~h}$ and deactivated with distilled water at a ratio of $3 \%$ $(\mathrm{m} / \mathrm{m})$. The other reagents including $n$-hexane, dichloromethane, anhydrous $\mathrm{Na}_{2} \mathrm{SO}_{4}$, concentrated $\mathrm{H}_{2} \mathrm{SO}_{4}$ were of analytical-grade (Beijing Chemical Reagent Factory, China). In addition, the extracting reagents including $\mathrm{n}$-hexane and dichloromethane were redistilled before use.

\subsection{Study area and sample collection}

Twenty-four sediment samples were collected in November 2002, from eight stations in East China Sea (Fig. 1). The sampling stations 4 and 5 were closed to the Yangtze Estuary and Hangzhou Bay, which might suffer from the potential risk of being polluted. Station 3 was a little far away from the flow trend of Yangtze River, where little influence could be caused by Yangtze River. Stations 7 and 8 were in the vicinity of the large city and the samples might be affected by municipal sewage. Other

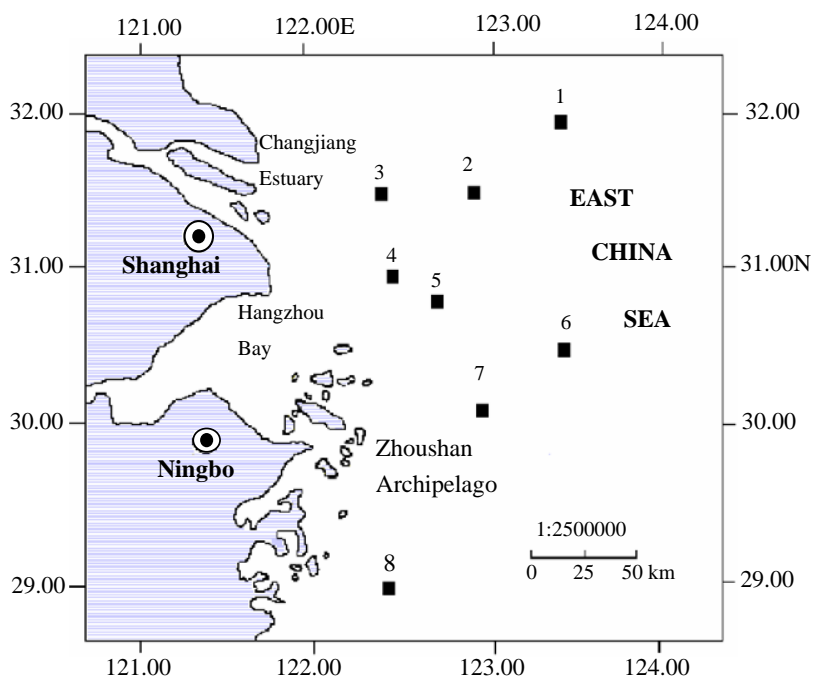

Fig. 1. Map of sampling locations of the East China Sea sediments.

samples from stations 1,2 and 6 were distant from the land, which could reflect the OCP pollution levels in this marginal sea.

Sediment core samples were obtained with a self-gravity diving and immediately sectioned at different depths using stainless plates after sampling, except for the two samples in stations 1 and 2. Sediment section of approximately $2 \mathrm{~cm}$ was taken from each layer. All the samples were immediately transferred to the laboratory and frozen at $-25{ }^{\circ} \mathrm{C}$ until use. The samples were freeze-dried and passed through a $63-\mu \mathrm{m}$ sieve. All the equipments used for sample collection, transportation, and preparation, were free from organochlorines. The detailed sample information was listed in Table 2.

\subsection{Extraction procedure}

The analytical procedure of OCPs residues was a modification of the method described by Lee et al. (2001). Approximately 10-g of freeze dried sample was extracted by sonication method. Above all, $80 \mathrm{~mL}$ of hexane-dichloromethane $(1: 1 \mathrm{v} / \mathrm{v})$ was added and the mixture was sonicated for $40 \mathrm{~min}$, then stood overnight (about $10 \mathrm{~h}$ ) and was sonicated for $30 \mathrm{~min}$ again. The extract was decanted, another $20 \mathrm{~mL}$ of hexane was added for $20 \mathrm{~min}$ of sonication extraction. The two extracts were combined and the activated $\mathrm{Cu}$ was added to remove sulfate. The organic layer was subsequently concentrated on a rotary evaporator to about $10 \mathrm{~mL}$ in a water bath at about $30^{\circ} \mathrm{C}$. The extract was removed to a separating funnel and added 5 $\mathrm{mL}$ of concentrated sulfate to get rid of the impurities for $2-$ 3 times. The organic phase was washed with $5 \% \mathrm{NaCl}$ solution. The extracts were concentrated again to about 1-2 $\mathrm{mL}$ by a rotary evaporator, and further purified with a column (12 $\mathrm{mm}$ i.d.) loaded with $8 \mathrm{~g}$ of Florisil and $2 \mathrm{~g}$ of anhydrous $\mathrm{Na}_{2} \mathrm{SO}_{4}$ from bottom to top in turn. The elution was subsequently carried out using $20 \mathrm{~mL}$ of hexane, and 20 
$\mathrm{mL}$ of hexane containing $10 \%(\mathrm{v} / \mathrm{v})$ dichloromethane. The first fraction of hexane effluent (about $10 \mathrm{~mL}$ ) was discarded which contained certain PCB congeners and other non-polar compounds. The rest of effluents containing the interested analytes were collected and reduced finally to a volume of $0.5 \mathrm{~mL}$ under a gentle stream of pure nitrogen for $\mathrm{GC}$ analysis.

\subsection{Instrumental analysis}

Total organic carbon contents were determined using Apollo 9000 TOC analyzer (Tekmar-Dohrmann Co., USA). The results were listed in Table 2. The identification and quantification of OCPs in the extracts were accomplished by an Agilent 6890A gas chromatography (GC) equipped with a ${ }^{63} \mathrm{Ni}$ electron capture detector $(\mu \mathrm{ECD})$ (USA) and a HP-1 fused silica capillary column $(30 \mathrm{~m}$ length $\times 0.25 \mathrm{~mm}$ id) coated with $100 \%$ dimethylsiloxane (film thickness $0.25 \mu \mathrm{m}$ ). One microliter of each sample was injected into the GC system for the separation of OCPs. The whole system was controlled by a Hewlett Packard workstation. The oven temperature increased from $80{ }^{\circ} \mathrm{C}$ to $200{ }^{\circ} \mathrm{C}$ (held for $1 \mathrm{~min}$ ) at a rate of $10{ }^{\circ} \mathrm{C} / \mathrm{min}$, and then programmed to $270{ }^{\circ} \mathrm{C}$ at $5{ }^{\circ} \mathrm{C} / \mathrm{min}$, held for 5 min. The temperatures of injector and detector were 250 ${ }^{\circ} \mathrm{C}$ and $280{ }^{\circ} \mathrm{C}$, respectively. High pure nitrogen was used as the carrier gas with a flow rate of $1.0 \mathrm{~mL} / \mathrm{min}$ and the make-up gas was controlled at $49 \mathrm{~mL} / \mathrm{min}$. Peak identification were conducted by the accurate retention time of each standard $( \pm 1 \%)$.

\subsection{Quality control and quality assurance}

The residue levels of OCPs were quantitatively determined by the external standard method using peak area. The correlation coefficients $(r)$ of calibration curves of OCPs were all higher than 0.998. The method detection limits (MDLs) of OCPs were described as 3:1 signal versus noise value $(\mathrm{S} / \mathrm{N})$. For every set of 8 samples, a procedural blank and a spiked sample with standards were run to check for the interference and cross-contamination. Table 1 illustrated

Table 1

The recoveries, method detection limits (MDLs), and the relative standard derivation (RSD) of the used analytical procedure

\begin{tabular}{lclc}
\hline Pesticides & $\begin{array}{l}\text { Recovery } \\
(\%)\end{array}$ & $\begin{array}{l}\text { MDLs } \\
(\mathrm{ng} / \mathrm{g} \mathrm{dw})\end{array}$ & $\begin{array}{l}\text { RSD (\%) } \\
\left(n^{\mathrm{a}=5)}\right.\end{array}$ \\
\hline$\alpha-\mathrm{HCH}$ & 98 & 0.05 & 4 \\
$\beta-\mathrm{HCH}$ & 90 & 0.20 & 8 \\
$\gamma-\mathrm{HCH}$ & 95 & 0.06 & 7 \\
$\delta$-HCH & 88 & 0.12 & 9 \\
$p, p^{\prime}-\mathrm{DDE}$ & 103 & 0.06 & 7 \\
$p, p^{\prime}-\mathrm{DDD}$ & 96 & 0.08 & 6 \\
$o, p^{\prime}-\mathrm{DDT}$ & 92 & 0.20 & 7 \\
$p, p^{\prime}-\mathrm{DDT}$ & 90 & 0.23 & 12 \\
\hline
\end{tabular}

\footnotetext{
${ }^{\text {a }}$ Five times repeated measurements.
}

the recoveries, MDLs and relative standard derivation (RSD) of the method. The MDLs ranged from $0.05 \mathrm{ng} / \mathrm{g}$ $\mathrm{dw}$ for $\alpha-\mathrm{HCH}$ to $0.23 \mathrm{ng} / \mathrm{g} \mathrm{dw}$ for $p, p^{\prime}$-DDT. The spiked recoveries of OCPs using $5 \mathrm{ng}$ of composite standards were in the range of $88-103 \%$ and the RSD values ranged from 4 to 12 . These parameters confirmed the practicability of the analytical protocols herein in the determination of OCP residues in the sediments.

\section{Results and discussion}

\subsection{Residue levels of $\mathrm{HCH}$ and DDT in sediments}

The samples analysed for the $\mathrm{HCH}$ and DDT included 8 surface sediments and 16 vertical sediments at different depths. The isomer concentrations of OCPs in sediments were summarized in Table 2. For the surface sediments, the residues of $\mathrm{HCH}$ and DDT ranged from $<0.05$ to $1.45 \mathrm{ng} / \mathrm{g}$ (mean $0.76 \mathrm{ng} / \mathrm{g}$ ), $<0.06$ to $6.04 \mathrm{ng} / \mathrm{g}$ (mean $3.05 \mathrm{ng} / \mathrm{g}$ ) based on dry weight, respectively. Concentrations of $\Sigma \mathrm{HCH}$ in sediments samples were much lower than those of $\Sigma$ DDT. This trend is consistent with the previous observations on the contamination of OCPs in sediments in China (Ma et al., 2001; Zhou et al., 2001). There is no quantitative information to prove that the amount of technical $\mathrm{HCH}$ used was smaller than that of DDT. A most likely explanation for the current relatively lower concentrations of HCHs in sediments is due to the differences in physicochemical and biochemical properties, wherein HCHs have higher water solubility, vapor pressure and biodegradability, and lower lipophilicity and particle affinity compared to the DDTs. DDTs tend to remain in the particulate phase longer than HCHs (Nhan et al., 2001).

For the vertical sediments, the $\Sigma \mathrm{HCH}$ and $\Sigma$ DDT were in the range of $<0.05-2.52 \mathrm{ng} / \mathrm{g},<0.06-10.94 \mathrm{ng} / \mathrm{g} \mathrm{dw}$, respectively. The occurrence of the maximum residue concentration existed in the vertical sediments, which reflected a more extensive use of OCPs in China in the past. These contaminants entered the aquatic ecosystem through effluents discharge, atmospheric deposition, runoff, and other means. In fact, China, India and the former Soviet Union represented the largest producers and users of HCH and DDT in 1980s. As an agricultural country, China was estimated to have about 14 million $\mathrm{hm}^{2}$ of farmland contaminated with OCP in1983. Large amount of OCPs was used in the agricultural area along the Yangtze River. Abundant water and sediments loads of Yangtze River play an important role on the distribution of the OCPs in the East China Sea. So the contribution of OCPs contamination in this region by run off from farmland and other agricultural activities should be emphasized.

\subsection{Distribution of $\mathrm{HCH}$ and $\mathrm{DDT}$}

According to Figs. 1 and 2, we could find that the concentrations of $\mathrm{HCH}$ and DDT in the surface sediments varied among sampling locations. The residue levels of OCP in the sediments from sites near seashore (Stations 4, 5, 7 and 8) were higher than those in the sites far from the land (Stations 1, 2, 3 and 6). The highest levels of $\Sigma$ HCH and $\Sigma$ DDT were found in the samples from station 4 and the second highest pollution levels 
Table 2

Sampling details and the determination results of selected OCPs (ng/g dw)

\begin{tabular}{|c|c|c|c|c|c|c|c|c|c|c|c|c|c|}
\hline $\begin{array}{l}\text { Sample } \\
\text { code }\end{array}$ & $\begin{array}{l}\text { Sampling } \\
\text { locations }\end{array}$ & $\begin{array}{l}\text { Sediments } \\
\text { sections }^{\mathrm{a}}\end{array}$ & $\begin{array}{l}\text { TOC } \\
(\mathrm{mg} / \mathrm{g})\end{array}$ & $\alpha-\mathrm{HCH}$ & $\beta-\mathrm{HCH}$ & $\gamma-\mathrm{HCH}$ & $\delta-\mathrm{HCH}$ & $\Sigma \mathrm{HCH}$ & $p, p^{\prime}-\mathrm{DDE}$ & $P p^{\prime}-\mathrm{DDD}$ & $o, p^{\prime}-\mathrm{DDT}$ & $p, p^{\prime}$-DDT & $\sum$ DDT \\
\hline 1 & $\begin{array}{l}31^{\circ} 59.893^{\prime} \mathrm{N} \\
123^{\circ} 30.195^{\prime} \mathrm{E}\end{array}$ & $0 \mathrm{~cm}$ & 3.03 & 0.25 & 0.19 & 0.13 & 0.15 & 0.73 & 0.73 & 0.75 & $<0.20$ & $<0.23$ & 1.48 \\
\hline 2 & $\begin{array}{l}31^{\circ} 30.092^{\prime} \mathrm{N} \\
123^{\circ} 0.272^{\prime} \mathrm{E}\end{array}$ & $0 \mathrm{~cm}$ & 1.42 & $<0.05$ & $<0.2$ & $<0.06$ & $<0.12$ & $\mathrm{nq}$ & $<0.06$ & $<0.08$ & $<0.20$ & $<0.23$ & $\mathrm{nq}$ \\
\hline 3 & $\begin{array}{l}31^{\circ} 30.061^{\prime} \mathrm{N} \\
122^{\circ} 30.679^{\prime} \mathrm{E}\end{array}$ & $\begin{array}{l}0 \mathrm{~cm} \\
15 \mathrm{~cm} \\
30 \mathrm{~cm}\end{array}$ & $\begin{array}{l}3.76 \\
3.17 \\
5.84\end{array}$ & $\begin{array}{r}0.10 \\
<0.05 \\
1.06\end{array}$ & $\begin{array}{r}<0.2 \\
0.35 \\
0.42\end{array}$ & $\begin{array}{r}<0.06 \\
0.07 \\
<0.06\end{array}$ & $\begin{array}{r}<0.12 \\
0.16 \\
<0.12\end{array}$ & $\begin{array}{l}0.20 \\
0.58 \\
1.48\end{array}$ & $\begin{array}{l}1.22 \\
2.03 \\
0.46\end{array}$ & $\begin{array}{l}0.31 \\
1.02 \\
1.10\end{array}$ & $\begin{array}{l}<0.20 \\
<0.20 \\
<0.20\end{array}$ & $\begin{array}{r}1.23 \\
1.38 \\
<0.23\end{array}$ & $\begin{array}{l}2.76 \\
4.43 \\
1.56\end{array}$ \\
\hline 4 & $\begin{array}{l}31^{\circ} 0.460^{\prime} \mathrm{N} \\
122^{\circ} 29.870^{\prime} \mathrm{E}\end{array}$ & $\begin{array}{l}0 \mathrm{~cm} \\
10 \mathrm{~cm} \\
20 \mathrm{~cm} \\
30 \mathrm{~cm} \\
40 \mathrm{~cm}\end{array}$ & $\begin{array}{l}6.98 \\
6.14 \\
6.50 \\
5.58 \\
5.52\end{array}$ & $\begin{array}{l}0.40 \\
0.22 \\
0.49 \\
0.76 \\
0.49\end{array}$ & $\begin{array}{l}0.94 \\
0.71 \\
0.85 \\
1.19 \\
1.30\end{array}$ & $\begin{array}{r}0.12 \\
<0.06 \\
<0.06 \\
0.57 \\
<0.06\end{array}$ & $\begin{array}{r}<0.12 \\
<0.12 \\
<0.12 \\
<0.12 \\
<0.12\end{array}$ & $\begin{array}{l}1.45 \\
0.94 \\
1.34 \\
2.52 \\
1.79\end{array}$ & $\begin{array}{l}1.40 \\
1.25 \\
1.24 \\
2.11 \\
2.08\end{array}$ & $\begin{array}{l}1.76 \\
0.94 \\
1.49 \\
3.48 \\
4.86\end{array}$ & $\begin{array}{r}<0.20 \\
<0.20 \\
<0.20 \\
1.18 \\
1.09\end{array}$ & $\begin{array}{r}2.92 \\
<0.23 \\
<0.23 \\
1.28 \\
2.92\end{array}$ & $\begin{array}{l}6.07 \\
2.19 \\
2.72 \\
8.06 \\
10.94\end{array}$ \\
\hline 5 & $\begin{array}{l}30^{\circ} 41.866^{\prime} \mathrm{N} \\
122^{\circ} 43.798^{\prime} \mathrm{E}\end{array}$ & $\begin{array}{l}0 \mathrm{~cm} \\
10 \mathrm{~cm} \\
20 \mathrm{~cm} \\
30 \mathrm{~cm}\end{array}$ & $\begin{array}{l}9.26 \\
9.29 \\
8.31 \\
8.44\end{array}$ & $\begin{array}{l}0.33 \\
0.41 \\
0.21 \\
0.25\end{array}$ & $\begin{array}{l}0.74 \\
1.18 \\
0.67 \\
1.13\end{array}$ & $\begin{array}{r}<0.06 \\
0.26 \\
0.15 \\
0.21\end{array}$ & $\begin{array}{l}<0.12 \\
<0.12 \\
<0.12 \\
<0.12\end{array}$ & $\begin{array}{l}1.06 \\
1.85 \\
1.04 \\
1.58\end{array}$ & $\begin{array}{l}2.05 \\
1.76 \\
1.18 \\
0.56\end{array}$ & $\begin{array}{l}2.21 \\
2.53 \\
1.85 \\
3.03\end{array}$ & $\begin{array}{r}<0.20 \\
0.72 \\
<0.20 \\
0.92\end{array}$ & $\begin{array}{r}0.42 \\
1.66 \\
<0.23 \\
1.46\end{array}$ & $\begin{array}{l}4.68 \\
6.67 \\
3.04 \\
5.97\end{array}$ \\
\hline 6 & $\begin{array}{l}30^{\circ} 30.603^{\prime} \mathrm{N} \\
123^{\circ} 29.623^{\prime} \mathrm{E}\end{array}$ & $\begin{array}{l}0 \mathrm{~cm} \\
15 \mathrm{~cm}\end{array}$ & $\begin{array}{l}2.39 \\
2.96\end{array}$ & $\begin{array}{l}0.20 \\
0.42\end{array}$ & $\begin{array}{l}0.80 \\
0.60\end{array}$ & $\begin{array}{r}<0.06 \\
0.12\end{array}$ & $\begin{array}{l}<0.12 \\
<0.12\end{array}$ & $\begin{array}{l}1.00 \\
1.13\end{array}$ & $\begin{array}{l}0.27 \\
0.47\end{array}$ & $\begin{array}{l}0.54 \\
0.59\end{array}$ & $\begin{array}{l}<0.20 \\
<0.20\end{array}$ & $\begin{array}{l}<0.23 \\
<0.23\end{array}$ & $\begin{array}{l}0.81 \\
1.06\end{array}$ \\
\hline 7 & $\begin{array}{l}30^{\circ} 0.220^{\prime} \mathrm{N} \\
123^{\circ} 0.507^{\prime} \mathrm{E}\end{array}$ & $\begin{array}{l}0 \mathrm{~cm} \\
15 \mathrm{~cm}\end{array}$ & $\begin{array}{l}6.55 \\
6.34\end{array}$ & $\begin{array}{l}0.37 \\
0.30\end{array}$ & $\begin{array}{l}0.38 \\
0.29\end{array}$ & $\begin{array}{l}0.10 \\
0.20\end{array}$ & $\begin{array}{l}<0.12 \\
<0.12\end{array}$ & $\begin{array}{l}0.86 \\
0.79\end{array}$ & $\begin{array}{l}1.12 \\
1.25\end{array}$ & $\begin{array}{l}1.24 \\
0.76\end{array}$ & $\begin{array}{l}0.44 \\
1.06\end{array}$ & $\begin{array}{l}2.01 \\
0.62\end{array}$ & $\begin{array}{l}4.82 \\
3.68\end{array}$ \\
\hline 8 & $\begin{array}{l}29^{\circ} 0.098^{\prime} \mathrm{N} \\
122^{\circ} 30.665^{\prime} \mathrm{E}\end{array}$ & $\begin{array}{l}0 \mathrm{~cm} \\
10 \mathrm{~cm} \\
20 \mathrm{~cm} \\
30 \mathrm{~cm} \\
40 \mathrm{~cm} \\
50 \mathrm{~cm}\end{array}$ & $\begin{array}{l}9.24 \\
8.60 \\
7.90 \\
6.77 \\
7.36 \\
6.75\end{array}$ & $\begin{array}{r}0.11 \\
<0.05 \\
0.10 \\
<0.05 \\
0.12 \\
0.24\end{array}$ & $\begin{array}{l}0.64 \\
0.36 \\
0.52 \\
0.80 \\
0.63 \\
0.46\end{array}$ & $\begin{array}{r}<0.06 \\
0.22 \\
<0.06 \\
<0.06 \\
<0.06 \\
<0.06\end{array}$ & $\begin{array}{l}<0.12 \\
<0.12 \\
<0.12 \\
<0.12 \\
<0.12 \\
<0.12\end{array}$ & $\begin{array}{l}0.75 \\
0.57 \\
0.63 \\
0.80 \\
0.75 \\
0.70\end{array}$ & $\begin{array}{l}1.20 \\
0.45 \\
0.69 \\
1.51 \\
0.67 \\
0.21\end{array}$ & $\begin{array}{l}1.54 \\
1.75 \\
1.15 \\
1.59 \\
1.17 \\
2.89\end{array}$ & $\begin{array}{r}0.41 \\
<0.20 \\
0.42 \\
<0.20 \\
<0.20 \\
<0.20\end{array}$ & $\begin{array}{r}1.01 \\
<0.23 \\
1.02 \\
<0.23 \\
<0.23 \\
<0.23\end{array}$ & $\begin{array}{l}4.16 \\
2.20 \\
3.28 \\
3.10 \\
1.85 \\
3.10\end{array}$ \\
\hline
\end{tabular}

nq: not to be quantified.

${ }^{\text {a }} 0 \mathrm{~cm}$ represents surface sediment.

existed in station 7. There was no detectable isomer in sediments from station 2, where the sediment was silt type and had a low organic matter. $\Sigma$ DDT concentration in the surface sediments was correlated well with TOC content $\left(r^{2}=0.71, p<0.05\right)$. However, the distribution of $\Sigma \mathrm{HCH}$ didn't show any correlation with TOC contents. The distribution difference can be caused by many possible factors such as historic usage, physicochemical properties and others. This relationship was also observed in the previous work (Lee et al., 2001).

For the vertical distribution, residue OCPs levels in three typical sediment cores were depicted in Fig. 3. It was found that in station 4 core sediments, the recorded concentrations of OCPs varied significantly with different sediments depths, especially for

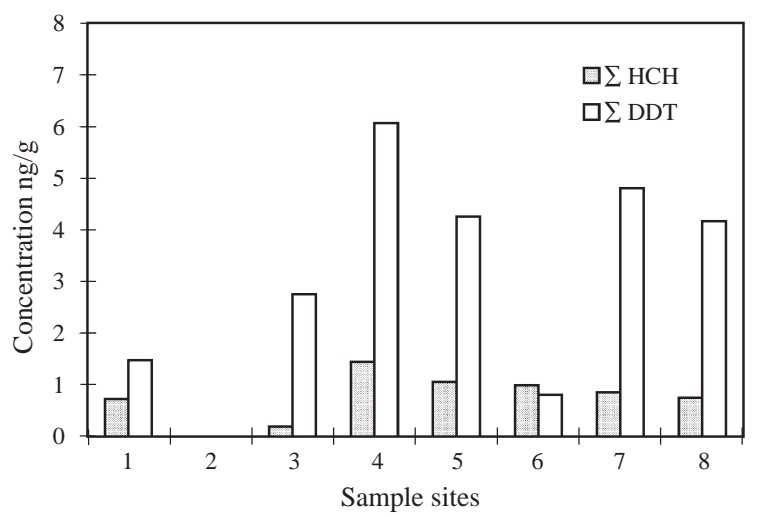

Fig. 2. The distribution of $\Sigma \mathrm{HCH}$ and $\Sigma$ DDT in the surface sediments.
DDT. The maximum of HCH (2.52 ng/g) and DDT (10.94 ng/g) were both found in station 4 core at depth of $30 \mathrm{~cm}$ and $40 \mathrm{~cm}$, respectively. These sediments located near the mouth of the Yangtze River, which originated primarily from erosion of the land, municipal sewage from Yangtze River and Qiantang River, which may be a reason affecting residues of OCP in the sediments. For the samples from station 5 , this effect was not remarkable with the long distance from the outlet and deeper sediments due to the dilution by seawater compared with station 4 core samples. In station 8 sediment core, however, samples were contaminated with low levels of $\mathrm{HCH}$ and DDT, which indicated the use of $\mathrm{HCH}$ and DDT in the municipal played a minor role.

\subsection{Compositions of $\mathrm{HCH}$ and $\mathrm{DDT}$}

The percentages of different isomers in surface sediments were shown in Fig. 4 (a: for $\mathrm{HCH}$; b: for DDT). The use of technical-grade $\mathrm{HCH}$ and lindane (purified ã-HCH), which has been used as broad spectrum insecticide for agricultural purpose, has been banned or restricted in many countries since 1970s. In China, the commonly used $\mathrm{HCHs}$ were technical mixtures containing $\alpha-, \beta-, \gamma-$, and $\delta$-isomers of $55-80 \%, 5-14 \%, 8-$ $15 \%$, and $2-16 \%$, respectively. Therefore, the predominant of $\alpha-$ isomer in some environmental samples reflected the recent use of technical HCH (Doong et al., 2002). In this study, $\beta-\mathrm{HCH}$ was the predominant composition and existed in most of the sediments. The isomers of $\alpha-, \beta-, \gamma-$, and $\delta-\mathrm{HCH}$ herein were observed to contribute about $29.0 \%, 62.7 \%, 5.7 \%$ and $2.5 \%$, respectively. Great changes occurred compared with its original components. The properties of lower vapor pressure and less 
(a)

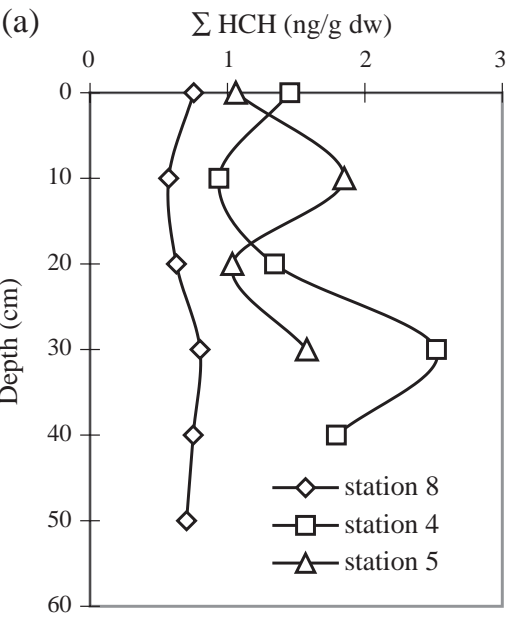

(b)

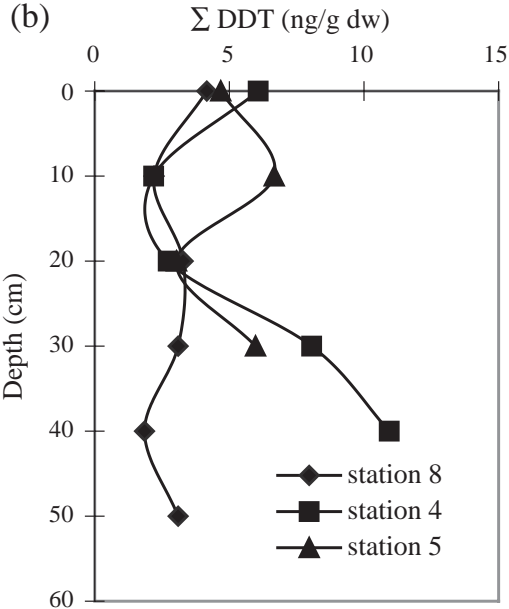

Fig. 3. Vertical distribution of $\Sigma H C H$ and $\Sigma$ DDT in sediment cores (a, HCH; b, DDT).

degradable of $\beta-\mathrm{HCH}$ relative to other $\mathrm{HCHs}$ accounted for the elevated percentage of $\beta-\mathrm{HCH}$. After long time aging, $\alpha$ - and $\gamma-$ $\mathrm{HCH}$ could be transformed into $\beta-\mathrm{HCH}$ (Willett et al., 1998; Walker, 1999).

DDT can be biodegraded to DDE under aerobic condition and to DDD under anaerobic condition, the relative concentration of the parent DDT compound and its metabolites, DDD and DDE, can be used as indicative indices for assessing the possible pollution sources (Doong et al., 2002). DDT compositions in this study significantly varied with different sampling sites. The percentage of $p, p^{\prime}$-DDT ranged from 0 to $48 \%$ with a mean value of $20 \%$. The ratio of $(\mathrm{DDE}+\mathrm{DDD}) / \Sigma \mathrm{DDT}>0.5 \mathrm{can}$ be thought to be subjected to a long-term weathering (Hites and Day, 1992; Hong et al., 1999). Here the mean ratio of $(\mathrm{DDE}+\mathrm{DDD}) / \Sigma \mathrm{DDT}$ in the surface sediments was 0.67 , which indicated that the degradation occurred significantly after the official ban of HCH and DDT in 1983. However, possible point pollution source could not be excluded just based on the results described above, because these pollution events are usually site and situation specific, occur on a relatively small scale, and are typically driven by water runoff. In addition, several recent studies reported high DDT residues in sediments or animal tissues, and revealed a new input of DDT, especially in South China (Klumpp et al., 2002; Mai et al., 2002; Wu et al., 1999; Ma et al., 2001).

\section{Conclusion}

This work investigated contamination status of the $\mathrm{HCH}$ and DDT in near shore marine environment from the East China Sea. DDTs are the major residue contaminants. Compared with their original compositions, great changes have occurred due to transformation and degradation of the contaminants. Concentrations and compositions of OCPs varied significantly with different sampling sites. $\Sigma$ DDT in the surface sediments was well correlated with TOC content, while $\mathrm{\Sigma} \mathrm{HCH}$ were independent. Generally, the sediments from near shore or estuary have higher contents of TOC and OCP residues. The contamination record indicated an extensive use of OCPs in the past, from the available data, the catchments from Yangtze River might greatly affect the OCP residues.

\section{Acknowledgements}

This work was jointly supported by the National Natural Science Foundation of China (20205008) and the Chinese Academy of Sciences (KZCX2-414).

(b)

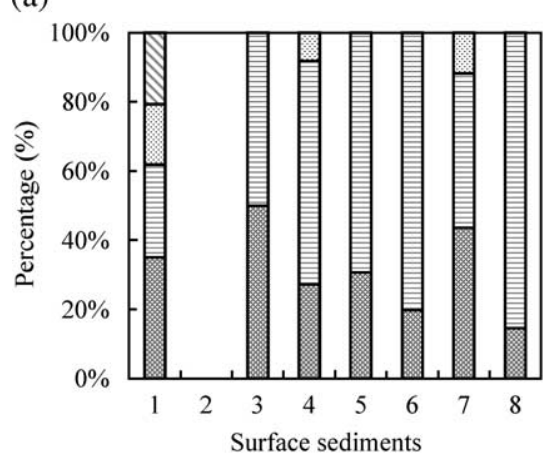

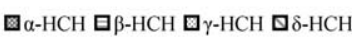

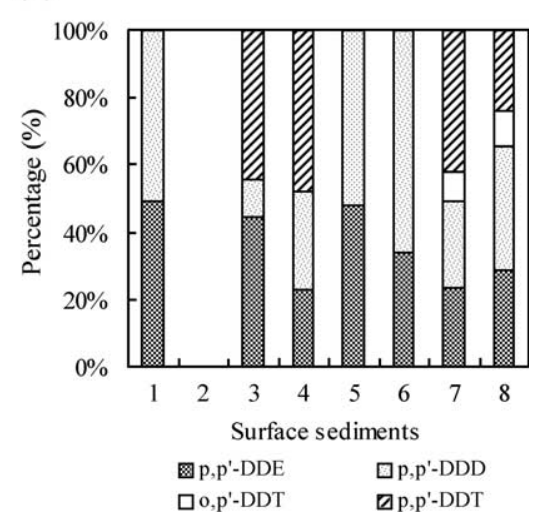

Fig. 4. Compositions of $\mathrm{HCH}$ and DDT in the surface sediments (a, HCH; b, DDT). 


\section{References}

Allen-Gil SM, Gubala CP, Wilson R, Landers DH, Wade TL, Sericano JL, et al. Organochlorine pesticides and polychlorinated biphenyls (PCBs) in sediments and biota from four US Arctic Lakes. Arch Environ Contam Toxicol 1997;33:378-87.

de Brito APX, Ueno D, Takahashi S, Tanabe S. Organochlorine and butyltin residues in walleye pollock (Theragra chalcogramma) from Bering sea, gulf of Alaska and Japan sea. Chemosphere 2002;46:401-11.

Doong RA, Sun YC, Liao PL, Peng CK, Wu SC. Distribution and fate of organochlorine pesticide residues in sediments from the selected rivers in Taiwan. Chemosphere 2002;48:237-46.

Hendy E, Peake BM. Organochlorine pesticides in a dated sediments core from Mapua, Waimea Inlet, New Zealand. Mar Pollut Bull 2002;32: $751-4$.

Hites RK, Day HR. Unusual persistent of DDT in some western USA soils. Bull Environ Contam Toxicol 1992;48:259-64.

Hong $\mathrm{H}$, Chen $\mathrm{W}$, Xu L, Wang X, Zhang L. Distribution and fate of organochlorine pollutants in the Pearl River estuary. Mar Pollut Bull 1999;39:376-82.

Hong SH, Yim UH, Shim WJ, Oh JR, Lee IS. Horizontal and vertical distribution of $\mathrm{PCBs}$ and chlorinated pesticides in sediments from Masan Bay, Korea. Mar Pollut Bull 2003;46:244-53.

Iwata H, Tanabe S, Sakai N, Nishimura A, Tatsukawa R. Geographical distributions of persistent organochlorines in air, water and sediments from Asia and Oceania and their implications for global redistribution from lower latitudes. Environ Pollut 1994;85:15-33.

Iwata H, Tanabe S, Ueda K, Tatsukawa R. Persistent organochlorine residues in air, water, sediments, and soils from the lake Baikal region, Russia. Environ Sci Technol 1995;29:792-801.

Klumpp DW, Huasheng H, Humphrey C, Xinhong W, Codi S. Toxic contaminants and their biological effects in coastal waters of Xiamen, China: I. Organic pollutants in mussels and fish tissues. Mar Pollut Bull 2002;44:752-60.
Lee KT, Tanabe S, Koh CH. Distribution of organochlorine pesticides in sediments from Kyeonggi Bay and nearby areas, Korea. Environ Pollut 2001;114:207-13.

Ma M, Feng Z, Guan C, Ma Y, Xu H, Li H. DDT, PAH and PCB in sediments from the intertidal zone of the Bohai sea and the Yellow sea. Mar Pollut Bull 2001;42:132-6.

Mai BX, Fu JM, Sheng GY, Kang YH, Lin Z, Zhang G, et al. Chlorinated and polycyclic aromatic hydrocarbons in riverine and estuarine sediments from Pearl River Delta, China. Environ Pollut 2002;117:457-74.

Nhan DD, Carvalho FP, Am NM, Tuan NQ, Yen NTH, Villenueve JP, et al. Chlorinated pesticides and PCBs in sediments and molluscs from freshwater canals in the Hanoi region. Environ Pollut 2001; 112:311-20

Tanabe S, Tatsukawa R, Kawano M, Hidaka H. Global distribution and atmosphere transport of chlorinated hydrocarbons: $\mathrm{HCH}(\mathrm{BHC})$ isomers and DDT compounds in the western Pacific, eastern Indian and Antarctic Oceans. J Ocean Soc Jpn 1982;38:137-48.

Walker K. Factors influencing the distribution of lindane and other hexachlorocyclohexanes in the environment. Environ Sci Technol 1999;33(2):4373-8.

Willett KL, Ulrich EM, Hites SA. Differential toxity and environmental fates of hexachlorocyclohexane isomers. Environ Sci Technol 1998; 32(15):2197-207.

Woodwell GM, Craig PP, Johnson HA. DDT in the biosphere: where does it go? Science 1971;174:1101-7.

Wu Y, Zhang J, Zhou Q. Persistent organochlorine residues in sediments from Chinese river/estuary systems. Environ Pollut 1999;105:143-50.

Zhang G, Parker A, House A, Mai B, Li X, Kang Y, et al. Sedimentary records of DDT and HCH in the Pearl River delta, South China. Environ Sci Technol 2002;36:3671-7.

Zhou JL, Maskaoui K, Qiu YW, Hong HS, Wang ZD. Polychlorinated biphenyl congeners and organochlorine insecticides in the water column and sediments of Daya Bay, China. Environ Pollut 2001; 113:373-84. 